OPEN ACCESS

Edited by:

Claudio Grassi,

Catholic University of the Sacred

Heart, Italy

Reviewed by:

Salvatore Fusco,

Fondazione Policlinico Universitario A. Gemelli, Università Cattolica del

Sacro Cuore, Italy

Eva Maria Jimenez-Mateos,

Trinity College Dublin, Ireland

*Correspondence:

Hong-Lin Huang

huangh/@usc.edu.cn

Xiao-Qing Tang

tangxq-usc@qq.com;

tangxq-usc@usc.edu.cn

tThese authors have contributed equally to this work

Received: 01 May 2019 Accepted: 25 July 2019 Published: 20 August 2019

Citation:

Wu L, Chen Y, Wang C-Y, Tang $Y-Y$,

Huang H-L, Kang $X$, Li X, Xie Y-R and

Tang X-Q (2019) Hydrogen Sulfide

Inhibits High Glucose-Induced

Neuronal Senescence by Improving Autophagic Flux via

Up-regulation of SIRT1.

Front. Mol. Neurosci. 12:194. doi: 10.3389/fnmol.2019.00194

\section{Hydrogen Sulfide Inhibits High Glucose-Induced Neuronal Senescence by Improving Autophagic Flux via Up-regulation of SIRT1}

\author{
Lei Wu ${ }^{1,2 \dagger}$, Ying Chen ${ }^{1,2,3 \dagger}$, Chun-Yan Wang ${ }^{2 \dagger}$, Yi-Yun Tang ${ }^{1}$, Hong-Lin Huang ${ }^{2 *}$, \\ Xuan Kang ${ }^{4}$, Xiang $\mathrm{Li}^{4}$, Yu-Rong $\mathrm{Xie}^{5}$ and Xiao-Qing Tang ${ }^{1,2,4 *}$
}

${ }^{1}$ Institute of Neuroscience, Hengyang Medical College, University of South China, Hengyang, China, ${ }^{2}$ Hunan Province Cooperative Innovation Center for Molecular Target New Drug Study, Institute of Pharmacy and Pharmacology, University of South China, Hengyang, China, ${ }^{3}$ Department of Pharmacology, The Central Hospital of Hengyang, Hengyang, China, ${ }^{4}$ Institute of Neurology, the First Affiliated Hospital, University of South China, Hengyang, China, ${ }^{5}$ College of Chemistry and Chemical Engineering, University of South China, Hengyang, China

Hyperglycemia, a key characteristic and risk factor for diabetes mellitus (DM), causes neuronal senescence. Hydrogen sulfide $\left(\mathrm{H}_{2} \mathrm{~S}\right)$ is a novel neuroprotectant. The present work was to investigate the potential effect of $\mathrm{H}_{2} \mathrm{~S}$ on hyperglycemia-induced neuronal senescence and the underlying mechanisms. We found that $\mathrm{NaHS}$, a donor of $\mathrm{H}_{2} \mathrm{~S}$, inhibited high glucose (HG)-induced cellular senescence in HT22 cells (an immortalized mouse hippocampal cell line), as evidenced by a decrease in the number of senescence associated- $\beta$-galactosidase (SA- $\beta$-gal) positive cells, increase in the growth of cells, and down-regulations of senescence mark proteins, p16 INK4a and p21 CIP1. NaHS improved the autophagic flux, which is judged by a decrease in the amount of intracellular autophagosome as well as up-regulations of LC3II/I and P62 in HG-exposed HT22 cells. Furthermore, blocked autophagic flux by chloroquine (CQ) significantly abolished NaHS-exerted improvement in the autophagic flux and suppression in the cellular senescence of $\mathrm{GH}$-exposed $\mathrm{HT} 22$ cells, which indicated that $\mathrm{H}_{2} \mathrm{~S}$ antagonizes HG-induced neuronal senescence by promoting autophagic flux. We also found that NaHS up-regulated the expression of silent mating type information regulation 2 homolog 1 (SIRT1), an important anti-aging protein, in HG-exposed HT22 cells. Furthermore, inhibition of SIRT1 by sirtinol reversed the protection of $\mathrm{H}_{2} \mathrm{~S}$ against HG-induced autophagic flux blockade and cellular senescence in HT22 cells. These data indicated that $\mathrm{H}_{2} \mathrm{~S}$ protects $\mathrm{HT} 22$ cells against HG-induced neuronal senescence by improving autophagic flux via up-regulation of SIRT1, suggesting $\mathrm{H}_{2} \mathrm{~S}$ as a potential treatment strategy for hyperglycemia-induced neuronal senescence and neurotoxicity.

Keywords: hydrogen sulfide, high glucose, SIRT1, autophagic flux, neuronal senescence 


\section{INTRODUCTION}

Diabetes mellitus (DM) increases the risk of central nervous system disease leading to encephalopathy (Sima et al., 2004), because hyperglycemia, the mainly characterized of DM, triggers neuronal damage (Fan et al., 2016; Kumar et al., 2017). Increasing evidence demonstrated that hyperglycemia induces neuronal senescence (Reno et al., 2013; Kaur et al., 2017; Yerra et al., 2017; Zhang et al., 2019). Therefore, increasing the defenses against hyperglycemia-induced neuronal senescence represents a future strategy for diabetic encephalopathy. Hydrogen sulfide $\left(\mathrm{H}_{2} \mathrm{~S}\right)$, the third gaseous signaling molecule (Wang, 2010), serves as an important neuroprotective agent in the central nervous system (Hu et al., 2009; Li et al., 2014; Wei et al., 2014). It has been confirmed that $\mathrm{H}_{2} \mathrm{~S}$ protects neuronal cells against stress-induced senescence (Liu et al., 2013; Xie et al., 2014). Furthermore, $\mathrm{H}_{2} \mathrm{~S}$ has emerged as an important therapeutic target for the treatment of neurological diseases (Suzuki et al., 2011; Si et al., 2013). Therefore, we speculated that $\mathrm{H}_{2} \mathrm{~S}$ also protects neurons against hyperglycemia-induced cellular senescence.

Autophagic flux, which regulates cell survival, metabolism and senescence (Mizushima et al., 2008; Shen et al., 2015), includes the formation of autophagic bodies and autophagic lysosomes, and the degradation of autophagy lysosomal inclusions (Lim et al., 2014). Recent evidence suggests that blocked autophagic flux contributes to neurodegeneration while improving autophagic flux has antagonistic effects on neurodegeneration (Nixon, 2013; Menzies et al., 2015; Lumkwana et al., 2017). Moreover, it has been reported that autophagic flux impairment induced by hyperglycemia is an essential pathogenic factor contributing to several DM-associated complications (Xie et al., 2016; Li Y. et al., 2017). Therefore, we hypothesized that block of autophagic flux mediates high glucose (HG)-induced neuronal senescence. Notably, $\mathrm{H}_{2} \mathrm{~S}$ plays an important role in regulating autophagic flux (Xie et al., 2015). Consequently, we speculated that the protection of $\mathrm{H}_{2} \mathrm{~S}$ against $\mathrm{HG}$-induced neuronal senescence is by improving autophagic flux.

Silent mating type information regulation 2 homolog 1 (SIRT1) is an $\mathrm{NAD}^{+}$-dependent deacetylase (Cohen et al., 2004; Bordone and Guarente, 2005). In the brain, SIRT1 is mainly expressed in neurons and has numerous biological functions, including regulation differentiation, metabolism, cell survival, and aging (Qadir and Anwar, 2017). It has been reported that SIRT1 activation attenuates hyperglycemia and plays an important mediatory role in treating diabetic complication (Li X. N. et al., 2017; Zhang Q. et al., 2018; Zhang Y. et al., 2018). Furthermore, SIRT1 improves autophagic flux (Zhang et al., 2016; Liu et al., 2017). Based on that $\mathrm{H}_{2} \mathrm{~S}$ up-regulates the expression of SIRT1 in neuron (Li et al., 2014), we hypothesized that SIRT1 mediates the protection of $\mathrm{H}_{2} \mathrm{~S}$ against $\mathrm{HG}$-triggered neuronal senescence by improving autophagic flux.

The present work identified that $\mathrm{H}_{2} \mathrm{~S}$ inhibits HG-induced cellular senescence in HT22 cells, an immortalized mouse hippocampal cell line (Liu et al., 2009), and that $\mathrm{H}_{2} \mathrm{~S}$ significantly attenuated HG-induced autophagy flux obstruction in HT22 cells. Furthermore, Chloroquine (CQ), an autophagic flux inhibitor, reversed the inhibitory roles of $\mathrm{H}_{2} \mathrm{~S}$ in HG-induced autophagic flux obstruction and cellular senescence in HT22 cells. We also found that $\mathrm{H}_{2} \mathrm{~S}$ significantly up-regulated SIRT1 expression in HG-exposed HT22 cells. Furthermore, Sirtinol, a SIRT1 inhibitor, reversed the inhibitory roles of $\mathrm{H}_{2} \mathrm{~S}$ in $\mathrm{HG}$-induced autophagic flux obstruction and cellular senescence in HT22 cells. Taken together, we demonstrated the protection of $\mathrm{H}_{2} \mathrm{~S}$ against $\mathrm{HG}$-induced cellular senescence of HT22 cells, as a result of improvement of autophagic flux via up-regulation of SIRT1.

\section{MATERIALS AND METHODS}

\section{Materials}

Glucose, Sodium hydrosulfide (NaHS, a donor of $\mathrm{H}_{2} \mathrm{~S}$ ), CQ (inhibitor of autophagic flux), 3-methyladenine (3-MA, inhibitor of autophagic flux), Sirtinol (the specific inhibitor of SIRT-1), and trypan blue were obtained from Sigma Chemical Company (St. Louis, MO, USA). Specific monoclonal antibodies p62 and LC3 were purchased from Cell Signaling Technology. Specific monoclonal anti-SIRT1 antibody was obtained from Abcam (Hong Kong, China). Specific antibodies of $\mathrm{p} 16^{\mathrm{INK} 4 \mathrm{a}}$ and $\mathrm{p} 21^{\mathrm{CIP} 1}$ were purchased from OriGene Technologies.

\section{Methods}

\section{Cell Cultures}

The mouse hippocampal neuron HT22 cell line was obtained from China Center for Type Culture Collection (Wuhan, China) and was used for all experiments. The cells were grown in Dulbecco's Modified Eagle's Medium (DMEM), which contains $10 \% \mathrm{FBS}, 100 \mathrm{IU} / \mathrm{mL}$ of penicillin and $100 \mathrm{mg} / \mathrm{mL}$ of streptomycin, at $37^{\circ} \mathrm{C}$ and $5 \% \mathrm{CO}_{2}$, under humidified atmosphere. The culture medium was changed every 3 days to ensure stable nutritional level.

\section{Senescence Associated- $\beta$-Galactosidase (SA- $\beta$-gal) Assay}

HT22 cells were fixed with $4 \%$ paraformaldehyde in $0.1 \mathrm{M}$ phosphate-buffered saline (PBS) for $10 \mathrm{~min}$. After three washes with PBS, HT22 cells were dyed with senescence associated- $\beta$-galactosidase (SA- $\beta$-gal) incubation overnight at $37^{\circ} \mathrm{C}$ under dry environment. HT22 cells were observed under an optical microscope (CKX41 SF, OLYMPUS, Japan). Living cells displayed normal nuclear size and morphology, whereas senescent cells with the characteristic morphology (enlarged and flattened) and positivity or SA- $\beta$-gal staining (turquoise color). The number of SA- $\beta$ gal-positive cell was counted to determine the percentage of senescent cells.

\section{HT22 Cells Growth Curve Draw by Trypan Blue Counting}

HT22 cells in logarithmic growth phase were seeded in 24-well plate with $1 \times 10^{4}$ cells at each well. After the density of HT22 cells at $80 \%$, cells were exposed to different experimental treatment. Three holes were randomly sampled for trypan blue count every day and counted for 7 days. For trypan blue 
staining, cell suspension was incubated with trypan blue in equal volume for $2 \mathrm{~min}$ and counting the unstained living cells on hemocytometer. The growth curve of the cell was plotted with the mean value of cell density per day as the ordinate and the growing days as the abscissa.

\section{Transmission Electron Microscope}

HT22 cells in logarithmic phase growth were seeded in a culture dish and were exposed to different experimental treatment for 48 h. After the treatment, cells were washed twice with PBS and fixed with $2.5 \%$ glutaraldehyde solution for $30 \mathrm{~min}$ at $4^{\circ} \mathrm{C}$. Cells were harvested in a $1.5 \mathrm{ml}$ of EP tube with $2.5 \%$ glutaraldehyde solution and conserved at $4^{\circ} \mathrm{C}$. Samples were tested in Shanghai Fu cheng biology co., Ltd. Briefly, cells were dehydrated, embedded, sliced into $60 \mathrm{~nm}$ sections and stained with uranyl acetate at room temperature for $15 \mathrm{~min}$, followed by lead citrate at room temperature for $15 \mathrm{~min}$. Autophagosome and autolysosome formation were observed by transmission electron microscope.

\section{Western Blots Analysis}

HT22 cell lysates were used to detect the protein expressions of p16 ${ }^{\mathrm{INK} 4 \mathrm{a}}, \mathrm{p} 21^{\mathrm{CIPL}}$, SIRT1, LC3, and p62. After the exposure was terminated, cells were washed with PBS and then lysed in an ice-cold lysis buffer $(20 \mathrm{mM}$ Tris- $\mathrm{HCl}, \mathrm{pH} 7.5,150 \mathrm{mM}$ $\mathrm{NaCl}, 1 \%$ Triton X-100, $1 \mathrm{mM}$ phenyl methyl sulphonyl fluoride (PMSF), $1 \mathrm{mM} \mathrm{Na} \mathrm{VO}_{4}$, leupeptin, and EDTA) for $30 \mathrm{~min}$. Liquid supernatant was collected after centrifugation for $10 \mathrm{~min}$ at 5,000 $\mathrm{g}$. The protein concentration was determined by BCA Protein Assay Kit (Beyotime, Shanghai, China). The samples were diluted with sample buffer (Beyotime, Shanghai, China) at $100^{\circ} \mathrm{C}$ for $5 \mathrm{~min}$ and were separated by $10 \%$ sodium dodecyl sulfate-polyacrylamide gel (SDS-PAGE). And then, the proteins were transferred electrophoretically to polyvinylidene fluoride (PVDF) membranes. Non-specific protein binding was incubated with $5 \%$ non-fat dried milk in TBST buffer ( $\mathrm{pH}$ 7.6, $3.03 \mathrm{~g}$ Tris base, $18.8 \mathrm{~g}$ glycine, $1 \mathrm{~g}$ SDS, plus $1 \mathrm{ml}$ Tween-20) for $2 \mathrm{~h}$ at room temperature. The membranes were incubated overnight at $4{ }^{\circ} \mathrm{C}$ with diluted primary antibody (antip16 ${ }^{\mathrm{INK} 4 \mathrm{a}}, 1: 2,000$; anti-p21 ${ }^{\mathrm{CIPL}}, 1: 2,000$; anti-SIRT1, 1:2,000; anti-p62, 1:1,000 and anti-LC3, 1:1,000). The membranes were then washed three times for 5 min each time with TBST, and incubated with HRP-conjugated secondary antibody (1:5,000, Protein Tech, SA00001-2) at room temperature for $2 \mathrm{~h}$. Protein bands were analyzed using the enhanced chemiluminescence detection system (BeyoECL Plus kit, Beyotime, P0018). Integrated optical densities were analyzed by using ImageJ software.

\section{Statistical Analysis}

Statistical analysis of all data was performed by SPSS 18.0 software. Data are displayed as the mean \pm SEM. Umbers of the biological replicates $(n)$ are noted in the figure legends. The significance of intergroup differences was evaluated by LSD-t to compare the data of different experimental groups with multiple comparisons. Differences were considered significant at $P<0.05$.

\section{RESULTS}

\section{$\mathrm{H}_{2} \mathrm{~S}$ Antagonizes HG-Induced Cellular Senescence in HT22 Cells}

We investigated the effect of $\mathrm{H}_{2} \mathrm{~S}$ on $\mathrm{HG}$-induced cellular senescence in HT22 cells. As illustrated in Figure 1A, the cell growth curves show that the growth of HT22 cell exposed by HG $(27 \mathrm{mg} / \mathrm{ml}$, for $48 \mathrm{~h})$ was increased by pretreatment with 100,200 , or $400 \mu \mathrm{M}$ of $\mathrm{NaHS}$ for $30 \mathrm{~min}$ (Day $1, F_{(5,12)}=$ 39.718, $P<0.001$; Day 2, $F_{(5,12)}=83.543, P<0.001$; Day 3, $F_{(5,12)}=235.790, P<0.001$; Day $4, F_{(5,12)}=149.725$, $P<0.001$; Day 5, $F_{(5,12)}=65.619, P<0.001 ;$ Day 6, $F_{(5,12)}=10.661, P<0.001$; Day $\left.7, F_{(5,12)}=6.735, P<0.01\right)$, respectively. In addition, the number of SA- $\beta$-gal positive cell was increased in HT22 cells treated with $27 \mathrm{mg} / \mathrm{ml}$ of HG for $48 \mathrm{~h}\left(F_{(3.16)}=393.481, P<0.001\right)$; However, pretreated with NaHS $(200 \mu \mathrm{M}$ for $30 \mathrm{~min})$ reduced the number of SA- $\beta$-gal positives cell in HT22 cells exposed to $27 \mathrm{mg} / \mathrm{ml}$ of $\mathrm{HG}$ for $48 \mathrm{~h}\left(F_{(3,16)}=393.481, P<0.001\right.$, Figure 1B). Furthermore, pretreatment of HT22 cells with $200 \mu \mathrm{M} \mathrm{NaHS}$ for $30 \mathrm{~min}$ significantly reversed the up-regulation of p16 ${ }^{\mathrm{INK} 4 \mathrm{a}}\left(F_{(3,8)}=4.257, P<0.05\right.$; Figure $\left.1 \mathrm{C}\right)$ and $\mathrm{p} 21^{\mathrm{CIP} 1}$ $\left(F_{(3,8)}=3.559, P<0.05\right.$; Figure 1D) protein expression induced by $\mathrm{HG}(27 \mathrm{mg} / \mathrm{ml}$, for $48 \mathrm{~h})$. Taken together, these data indicated that $\mathrm{H}_{2} \mathrm{~S}$ inhibits HG-induced cellular senescence in HT22 cells.

\section{$\mathrm{H}_{2}$ S Rescues HG-Impaired Autophagic Flux in HT22 Cells}

To explore whether autophagic flux involves in the protection of $\mathrm{H}_{2} \mathrm{~S}$ against $\mathrm{HG}$-induced cellular senescence in HT22 cells, we investigated the effect of NaHS on the autophagic flux in HG-exposed HT22 cells. The number of autophagosomes in HT22 cells exposed to HG $(40.5 \mathrm{mg} / \mathrm{ml}$, for $48 \mathrm{~h})$ was higher than that of the control group, which was suppressed by pretreatment with NaHS $(200 \mu \mathrm{M}$, for 30 min; Figure 2A). In addition, after exposure to HG (27, $40.5 \mathrm{mg} / \mathrm{ml}$ ) for $48 \mathrm{~h}$, the expressions of LC3 II/I $\left(F_{(3,8)}=25.027, P<0.001\right.$; Figure 2B $)$ and P62 $\left(F_{(3,8)}=16.177\right.$, $P<0.01$; Figure 2C) were significantly increased in HT22 cells. However, pretreatment with NaHS $(200 \mu \mathrm{M}$, for $30 \mathrm{~min})$ significantly down-regulated the expressions of LC3 II/I $\left(F_{(3,8)}=4.452, P<0.05\right.$; Figure 2D) and P62 $\left(F_{(3,8)}=11.547, \quad P<0.05\right.$; Figure $\left.2 \mathbf{E}\right)$ in $\mathrm{HG}$-exposed HT22 cells. Collectively, these results demonstrated that $\mathrm{H}_{2} \mathrm{~S}$ reverses HG-induced autophagic flux block in HT22 cells.

\section{Blockage of Autophagic Flux Reverses the Improving Effect of $\mathrm{H}_{2} \mathrm{~S}$ on Autophagic Flux in HG-Exposed HT22 Cells}

3-MA and CQ are the specific autophagic flux inhibitors, which inhibit initial and late stage of autophagic flux (Caro et al., 1988; Ye et al., 2016), respectively. Next, we explored whether 3-MA and CQ abolish the improving effect of $\mathrm{H}_{2} \mathrm{~S}$ on autophagic flux in HG-exposed HT22 cells. We found that 


\section{A}

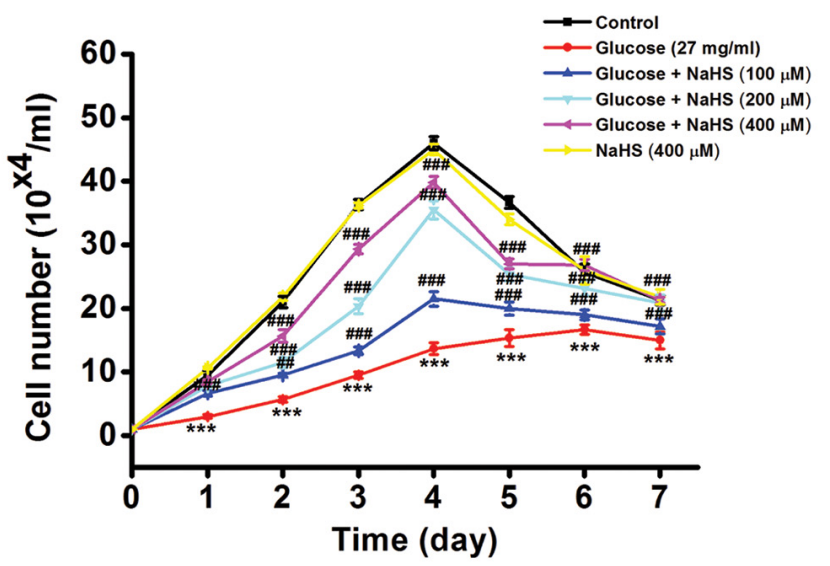

B
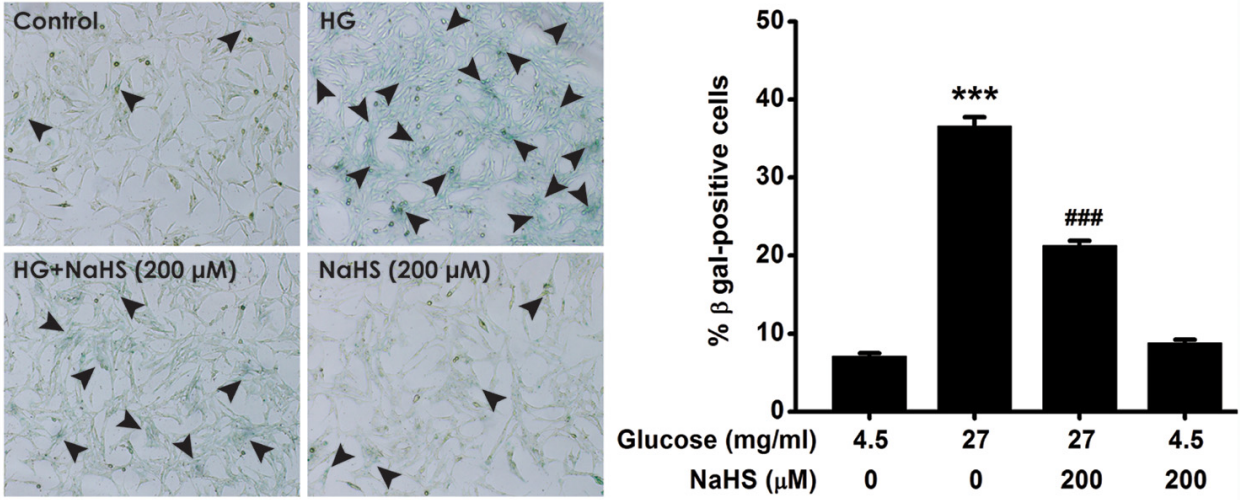

C

D


FIGURE 1 | Effect of hydrogen sulfide $\left(\mathrm{H}_{2} \mathrm{~S}\right)$ on high glucose (HG)-elicited cellular senescence in $\mathrm{HT} 22$ cells. (A) Cell growth curves were generated using Trypan blue stain assays. (B) Representative images of senescent cells that were stained using senescence associated- $\beta$-galactosidase (SA- $\beta$-gal; Left, Magnification $\times 100)$ and quantitative analysis of the SA- $\beta$-gal positive cells (Right). The black arrows indicate the senescent cells, (C,D) The expressions of p16 $6^{\mathrm{NK} 4 a}$ and p21 ${ }^{\mathrm{CIP1}}$ in HT22 cells were detected by Western blotting. Values were expressed as the mean $\pm \mathrm{SEM}, n=3$. ${ }^{*} P<0.05,{ }^{* * *} P<0.001$, vs. control group; ${ }^{\#} P<0.05$, ${ }^{\# \# P}<0.01,{ }^{\# \#} P<0.001$ vs. HG-treated alone group.

CQ $(10 \mu \mathrm{M})$ reversed the suppression of NaHS $(200 \mu \mathrm{M})$ in HG (40.5 $\mathrm{mg} / \mathrm{ml}$, for $48 \mathrm{~h}$ )-induced increase in the number of autophagosome (Figure $\mathbf{3 A}$ ) as well as upregulations of LC3II/LC3I $\left(F_{(4,10)}=6.151, P<0.05\right.$; Figure 3B $)$ and P62 $\left(F_{(4,10)}=13.498, P<0.01\right.$; Figure 3C) in HT22 cells. However,
3-MA (10 mM) had no significant effect on the suppressive effect of NaHS $(200 \mu \mathrm{M})$ on HG $(40.5 \mathrm{mg} / \mathrm{ml}$, for $48 \mathrm{~h})$-induced increase in the number of autophagosome (Figure 3D) as well as upregulations of LC3II/LC3I $\left(F_{(4,10)}=4.189, P>0.05\right.$; Figure 3E) and $\mathrm{P} 62\left(F_{(4,10)}=5.900, P>0.05\right.$; Figure 3F) 




B
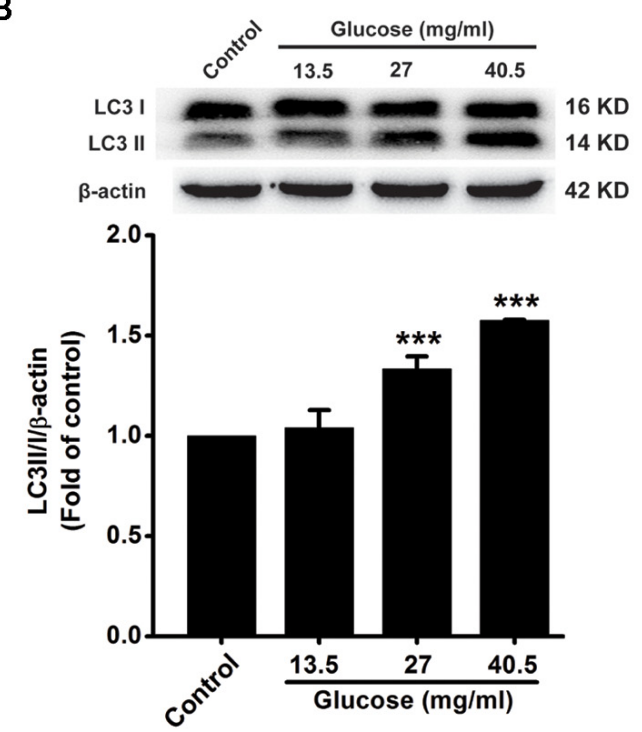

D

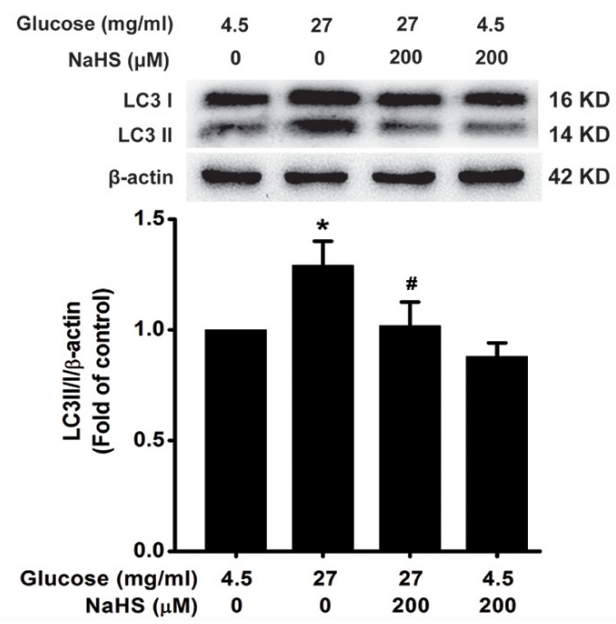

C
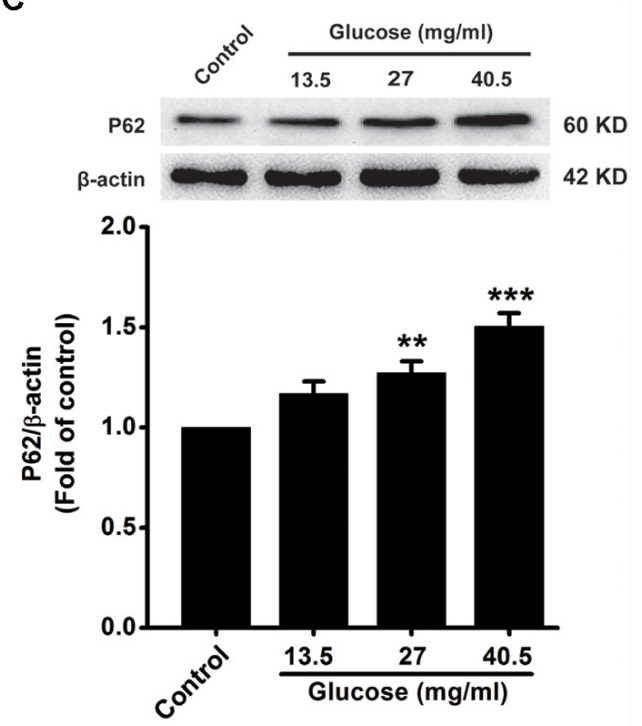

E
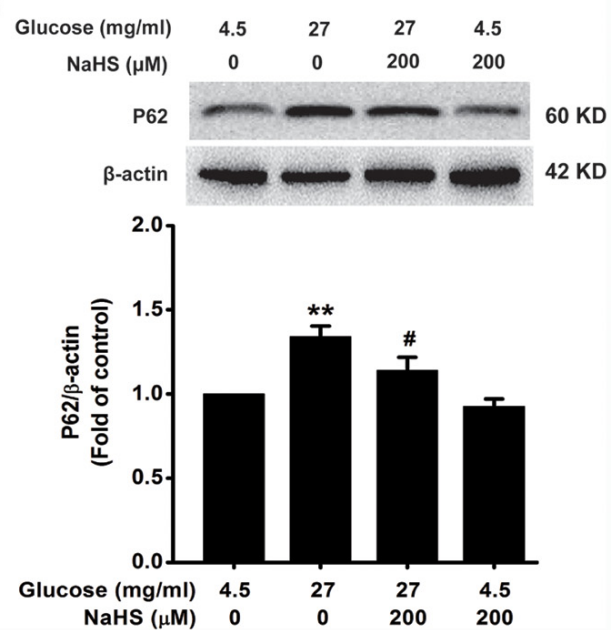

FIGURE 2 | Effect of $\mathrm{H}_{2} \mathrm{~S}$ on HG-elicited disruption of autophagic flux in HT22 cells. (A) Transmission electron microscope observed the number of autophagosome. The yellow arrows indicate autophagosome. (B-E) The expressions of LC3II/LC3I and P62 in HT22 cells were detected by Western blotting. Values were expressed as the mean $\pm \mathrm{SEM}, n=3 .{ }^{*} P<0.05,{ }^{* *} P<0.01,{ }^{* * *} P<0.001$, vs. control group; ${ }^{*} P<0.05$, vs. HG-treated alone group. 




FIGURE 3 | Effects of chloroquine (CQ) and 3-methyladenine (3-MA) on the improving role of $\mathrm{H}_{2} \mathrm{~S}$ in autophagic flux in $\mathrm{HG}$-exposed $\mathrm{HT} 22$ cells. (A,D) Transmission electron microscope images of HT22 cells showing the change in the number of autophagosome. The yellow arrows indicate autophagosome. (B,C,E,F) The expressions of LC3II/LC3I and P62 in HT22 cells were detected by Western blotting. Values were expressed as the mean \pm SEM, $n=3$. ${ }^{* *} P<0.01$, ${ }^{* * *} P<0.001$, vs. control group; ${ }^{\#} P<0.05$ ${ }^{\# \#} P<0.01$, \#\#\# $P<0.001$, vs. HG-treated alone group; $\& P<0.05$, \&\& $P<0.01$, vs. co-treated with $\mathrm{NaHS}$ and $\mathrm{HG}$ group.

in HT22 cells. Taken together, these results indicated that $\mathrm{H}_{2} \mathrm{~S}$ overcomes HG-induced disturbance in autophagic flux via restoring the late stage of autophagic flux.

\section{Blockage of Autophagic Flux by $\mathrm{CQ}$ Reverses the Protection of $\mathrm{H}_{2} \mathrm{~S}$ Against HG-Induced Cellular Senescence in HT22 Cells}

We further examined the effects of CQ and 3-MA on the protection of $\mathrm{H}_{2} \mathrm{~S}$ against $\mathrm{HG}$-induced cellular senescence in HT22 cells. Pretreatment with CQ $(10 \mu \mathrm{M})$ reversed the suppression of NaHS $(200 \mu \mathrm{M})$ in HG $(40.5 \mathrm{mg} / \mathrm{ml}$, for $48 \mathrm{~h})$ induced inhibition of the cell growth (Day 1, $F_{(4,10)}=32.703$, $P<0.001$; Day 2, $F_{(4,10)}=42.562, P<0.001$; Day 3, $F_{(4,10)}=94.889, P<0.001 ;$ Day $4, F_{(4,10)}=58.601, P<0.001 ;$ Day $5, F_{(4,10)}=42.892, P<0.001$; Day $6, F_{(4,10)}=26.198, P<0.01$; Day 7, $F_{(4,10)}=23.688, P<0.01$; Figure $\left.4 \mathrm{~A}\right)$, increase in the number of SA- $\beta$-gal positive cells $\left(F_{(4,20)}=330.457, P<0.001\right.$; Figure 4B), as well as up-regulations of p16 $6^{\mathrm{INK} 4 \mathrm{a}}\left(F_{(4,10)}=4.161\right.$, $P<0.05$; Figure 4C) and $\mathrm{p} 21^{\mathrm{CIP} 1}\left(F_{(4,10)}=11.886, P<0.05\right.$; Figure 4D) in HT22 cells. However, pretreated HT22 cells with 3-MA (10 mM) had no significant effect on the suppressive effect of NaHS $(200 \mu \mathrm{M})$ on HG $(40.5 \mathrm{mg} / \mathrm{ml}$, for $48 \mathrm{~h})$-induced inhibition of the cell growth (Day $1, F_{(4,10)}=16.885, P>0.05$; Day 2, $F_{(4,10)}=170.863, P<0.05 ;$ Day 3, $F_{(4,10)}=91.809$, $P>0.05 ;$ Day $4, F_{(4,10)}=94.120, P>0.05 ;$ Day $5, F_{(4,10)}=68.969$, $P>0.05$; Day 6, $F_{(4,10)}=44.611, P>0.05$; Day 7, $F_{(4,10)}=20.872$, $P>0.05$; Figure 4E), increase in the number of SA- $\beta$-gal positive cells $\left(F_{(4,20)}=185.297, P>0.05\right.$; Figure $\left.4 \mathrm{~F}\right)$, as well as up-regulations of $\mathrm{p} 16^{\mathrm{INK} 4 \mathrm{a}}\left(F_{(4,10)}=4.841, P>0.05\right.$; Figure 4G) and $\mathrm{p} 21^{\mathrm{CIP} 1}\left(F_{(4,10)}=5.801, P>0.05\right.$; Figure $\left.4 \mathrm{H}\right)$. These results indicated that improving autophagic flux contributes to $\mathrm{H}_{2} \mathrm{~S}$ exerted protection against HG-induced cellular senescence in HT22 cells.

\section{$\mathrm{H}_{2} \mathrm{~S}$ Up-Regulates SIRT1 Expression in HG-Treated HT22 Cells}

In order to ascertain whether the protective effect of $\mathrm{H}_{2} \mathrm{~S}$ is dependent on SIRT1, we first investigated the effect of $\mathrm{H}_{2} \mathrm{~S}$ on the expression of SIRT1. As showed in Figure 5A, the expression of SIRT1 in HT22 cells were increased by treatment with NaHS $(100,200$ or $400 \mu \mathrm{M})$ for $24 \mathrm{~h}\left(F_{(3,8)}=169.526, P<0.001\right)$. Furthermore, the down-regulation of SIRT1 caused by HG $(40.5 \mathrm{mg} / \mathrm{ml}$, for $48 \mathrm{~h}$ ) was reversed by pretreatment with NaHS $\left(200 \mu \mathrm{M}\right.$, for $30 \mathrm{~min} ; F_{(3,8)}=37.762, P<0.001$; Figure 5B). These data indicated that $\mathrm{H}_{2} \mathrm{~S}$ up-regulates the expression of SIRT1 in HT22 cells.

\section{Sirtinol, an Inhibitor of SIRT1, Reverses the Improving Effect of $\mathrm{H}_{2} \mathrm{~S}$ on Autophagic Flux in HG-Exposed HT22 Cells}

To confirm whether SIRT1 mediates the improving effect of $\mathrm{H}_{2} \mathrm{~S}$ on autophagic flux in HG-exposed HT22 cells, we explored whether the SIRT1 inhibitor, Sirtinol, reverses this improving effect of $\mathrm{H}_{2} \mathrm{~S}$ on autophagic flux. Pretreatment with Sirtinol $(15 \mu \mathrm{M})$ abolished the suppression of NaHS $(200 \mu \mathrm{M})$ in $\mathrm{HG}(40.5 \mathrm{mg} / \mathrm{ml}$, for $48 \mathrm{~h})$-induced increase in the number of autophagosome (Figure 6A) as well as up-regulations of LC3II/LC3I $\left(F_{(5,12)}=7.733, P<0.05\right.$; Figure 6B) and 


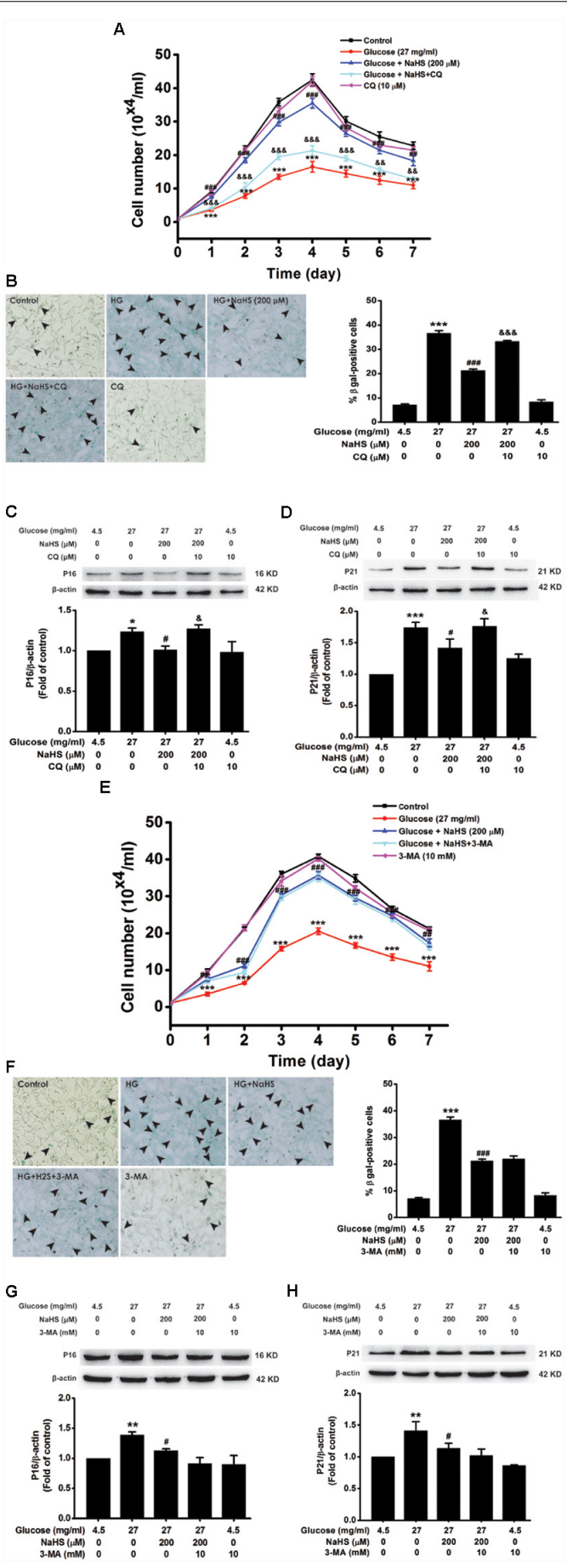

FIGURE 4 | Effects of $C Q$ and 3-MA on the protection of $\mathrm{H}_{2} \mathrm{~S}$ against HG-induced cellular senescence in HT22 cells. (A,E) Cell growth curves were generated by using Trypan blue stain assays. (B,F) Representative images of senescent cells that were stained for SA- $\beta$-gal (Left, Magnification $\times 10$ ) and quantitative analysis of the SA- $\beta$-gal positive cells (Right). The black arrows indicate the senescent cells, $n=5$. (C, D, G, H) The expressions of p16 INK4a and $\mathrm{p} 21^{\mathrm{CIP} 1}$ in $\mathrm{HT} 22$ cells were detected by Western blotting. Values were expressed as the mean \pm SEM, $n=3 .{ }^{*} P<0.05$, ${ }^{* *} P<0.01$, ${ }^{* * *} P<0.001$,

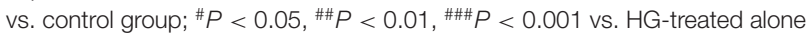
group. ${ }^{\&} P<0.05,{ }^{\& \&} P<0.01,{ }^{\& \& \&} P<0.001$, vs. co-treated with $\mathrm{NaHS}$ and HG group.
P62 protein $\left(F_{(5,12)}=29.863, P<0.001\right.$; Figure 6C) in HT22 cells, which indicated that inhibited SIRT1 by Sirtinol reverses the improving effect of $\mathrm{H}_{2} \mathrm{~S}$ on autophagic flux in HG-exposed HT22 cells.

\section{Sirtinol Abolishes the Protection of $\mathrm{H}_{2} \mathrm{~S}$ Against HG-Induced Cellular Senescence in HT22 Cells}

Next, we explored whether inhibited SIRT1 abolishes the protection of $\mathrm{H}_{2} \mathrm{~S}$ against HG-induced cellular senescence in HT22 cells. Pretreatment with Sirtinol $(15 \mu \mathrm{M})$ reversed the suppression of NaHS $(200 \mu \mathrm{M})$ in HG $(40.5 \mathrm{mg} / \mathrm{ml}$, for $48 \mathrm{~h})$ induced inhibition of the cell growth (Day 1, $F_{(5,12)}=29.984$, $P<0.01$; Day 2, $F_{(5,12)}=50.438, P<0.001$; Day 3, $F_{(5,12)}=181.255, P<0.001$; Day $4, F_{(5,12)}=256.034, P<0.001$; Day 5, $F_{(5,12)}=155.338, P<0.001$; Day 6, $F_{(5,12)}=65.111$, $P<0.001$; Day 7, $F_{(5,12)}=16.613, P<0.05$; Figure 7A), increase in the number of SA- $\beta$-gal positive cells $\left(F_{(5,24)}=368.555\right.$, $P<0.001$; Figure 7B), as well as upregulations of $\mathrm{p} 16^{\mathrm{INK} 4 \mathrm{a}}$ $\left(F_{(5,12)}=5.609, P<0.05\right.$; Figure 7C) and p $21^{\mathrm{CIP} 1}\left(F_{(5,12)}=6.522\right.$, $P<0.05$; Figure 7D) in HT22 cells, which indicated that inhibited SIRT1 by sirtinol reverses the protection of $\mathrm{H}_{2} \mathrm{~S}$ against HG-induced cellular senescence in HT22 cells.

\section{DISCUSSION}

Neuronal senescence plays key risk factors in hyperglycemiainduced neurotoxicity (Allen et al., 2005; Tomlinson and Gardiner, 2008). Our present work was to investigate whether $\mathrm{H}_{2} \mathrm{~S}$ prevents hyperglycemia-induced neuronal senescence and the underlying mechanisms. The main findings of the present study are as followings: (1) NaHS (a donor of $\mathrm{H}_{2} \mathrm{~S}$ ) inhibits HG-induced cellular senescence of HT22 cells; (2) NaHS restores HG-induced autophagic flux dysfunction in HT22 cells; (3) inhibition of autophagic flux by CQ reversed $\mathrm{H}_{2} \mathrm{~S}$-restored autophagic flux in HG-exposed HT22 cells; (4) CQ abolishes the protective effects of $\mathrm{H}_{2} \mathrm{~S}$ on HG-induced cellular senescence in HT22 cells; (5) $\mathrm{H}_{2} \mathrm{~S}$ upregulates the expression of SIRT1 protein in HG-exposed HT22 cells; and (6) sirtinol, an inhibitor of SIRT1 , not only reverses the improvement of $\mathrm{H}_{2} \mathrm{~S}$ in HG-induced autophagic flux disturbance in HT22 cells but also blocks the protection of $\mathrm{H}_{2} \mathrm{~S}$ against $\mathrm{HG}$-induced cellular senescence in HT22 cells. This is the first report that $\mathrm{H}_{2} \mathrm{~S}$ rescues HG-induced neuronal senescence by improving autophagic flux through up-regulation of SIRT1.

Accumulating evidence demonstrates that long-term hyperglycemia causes neurotoxicity (Liu et al., 2014; Bahniwal et al., 2017; Li Y. et al., 2017; Renaud et al., 2018). It is well established that neuronal senescence plays a crucial role in the neurotoxicity of hyperglycemia (Sinadinos et al., 2014; Song et al., 2016; Zhu et al., 2018). Therefore, strategies to preserve neuronal cells by increasing the defenses of hyperglycemia-induced neuronal senescence are emerging as promising therapeutic approaches to prevent hyperglycemia-induced neurotoxicity. Due to their higher metabolic demands, HT22 cells require higher levels of glucose in normal growth media $(25 \mathrm{mM}$ 
A



B



FIGURE 5 | Effect of $\mathrm{H}_{2} \mathrm{~S}$ on the expression of silent mating type information regulation 2 homolog 1 (SIRT1) in HT22 cells. (A) HT22 cells were treated with NaHS (100, 200 or 400 mM) for 24 h. (B) after pretreatment with NaHS (200 mM) for 30 min, HT22 cells were co-treated with HG (40.5 mg/ml) for 48 h. The expressions of SRT1 in HT22 cells were detected by Western blotting. Values were expressed as the mean \pm SEM, $n=3$. ${ }^{* * *} P<0.001$, vs. control group; \#\#\# $P<0.001$ vs. HG-treated alone group.

glucose; Ward and Ergul, 2016). We have previously confirmed that treatment of HT22 cells with HG $(150 \mathrm{mM})$ for $48 \mathrm{~h}$, the cell viability was decreased to $70 \%$ compared with the control group (Zhu et al., 2018). In order to eliminate the effect of HG concentration on alteration of osmolarity, we have previously found that equal concentration of mannitol (150 mM) had no significant effect on the cell viability compared with the control group (Zhu et al., 2018). Similarly, Song et al. (2016) used $200 \mathrm{mM}$ glucose to explore the effect of HG on senescence of neuronal cells. Therefore, in the present work, HT22 cells were exposed by $13.5-40.5 \mathrm{mg} / \mathrm{ml}$ of glucose to effectuate hyperglycemia-induced neuronal senescence in vitro. $\mathrm{H}_{2} \mathrm{~S}$, as a neuroprotector, has universal anti-senescence effects (Qi et al., 2012; Yang et al., 2013; Panthi et al., 2016), identifying as a potent preventive and therapeutic agent for senescence-associated disease (Zhang et al., 2013). Therefore, we explored whether $\mathrm{H}_{2} \mathrm{~S}$ prevents hyperglycemia-induced neuronal senescence. The SA- $\beta$-gal (Dimri et al., 1995; DebacqChainiaux et al., 2009) and trypan blue (Tennant, 1964) are main staining methods for identifying senescence cell. The $\mathrm{p} 16^{\mathrm{INK} 4 \mathrm{a}}$ (Baker et al., 2011) and p21 ${ }^{\mathrm{CIP1}}$ (Carreira et al., 2005) are the main cellular senescence biomarker protein. We examined these senescent makers to explore whether pretreatment with NaHS prevents HG-induced senescence in HT22 cells. Our results showed that NaHS decreased the number of SA- $\beta$-gal positive cells, increased the growth of cells, and down-regulated the expressions of senescence marker, p16 ${ }^{\mathrm{INK} 4 \mathrm{a}}$ and $\mathrm{p} 21^{\mathrm{CIP} 1}$, in HG-exposed HT22 cells. Our results indicated that $\mathrm{H}_{2} \mathrm{~S}$ antagonizes HG-induced cellular senescence in HT22 cells. It has been reported that $\mathrm{H}_{2} \mathrm{~S}$ reverses $\mathrm{H}_{2} \mathrm{O}_{2}$-induced senescence in SH-SY5Y cells (Xie et al., 2014). Thus, it is reasonable to believe $\mathrm{H}_{2} \mathrm{~S}$ as a potentially promising therapeutic approach to the treatment of HG-induced neuronal senescence.

Next, we explored the mechanisms underlying this inhibitory role of $\mathrm{H}_{2} \mathrm{~S}$ on HG-induced cellular senescence. Emerging evidence suggests that blockage of autophagic flux results in the decrease in degradation of misfolded proteins or damaged organelles, which in turn leads to cellular senescence (Lin et al., 2015; Han et al., 2016; Yin et al., 2017). In the present study, we found that accumulation of autophagosomes, increase in LC3II/I, and upregulation of P62 were displayed in HG-exposed HT22 cell. P62 connects between LC3 and ubiquitination substrate, which is degraded in autolysosomes (Bjørkøy et al., 2005). The aggregation of P62 is associated with autophagic degradation dysfunction (Komatsu and Ichimura, 2010). Thus, our results indicated that HG induces blockage of autophagic flux in HT22 cells. There is evidence that HG exposure reduces autophagic flux in cardiomyocyte (Hou et al., 2018). Therefore, we suggested that blockage of autophagic flux plays an important role in HG-induced senescence of HT22 cells. It has been reported that activating autophagic flux by $\mathrm{H}_{2} \mathrm{~S}$ prevents HG-induced injury in H9C2 cells (Yang et al., 2017). Moreover, $\mathrm{H}_{2} \mathrm{~S}$-mediated autophagic flux reduces serum triglyceride in rat liver (Sun et al., 2015). Therefore, we investigated whether improving autophagic flux plays a key role in the protection of $\mathrm{H}_{2} \mathrm{~S}$ against HG-induced cellular senescence in HT22 cells. Notably, NaHS reduced the number of autophagosomes, decreased the ratio of LC3II/I, and downregulated the expression of P62 in HG-exposed HT22 cell, which indicated the improving role of $\mathrm{H}_{2} \mathrm{~S}$ in autophagic flux. To further validate whether improving autophagic flux mediates the protection of $\mathrm{H}_{2} \mathrm{~S}$ against $\mathrm{HG}$-induced cellular 

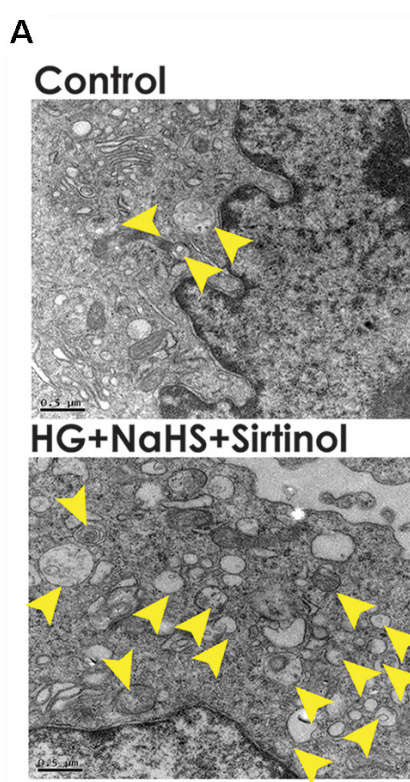

B
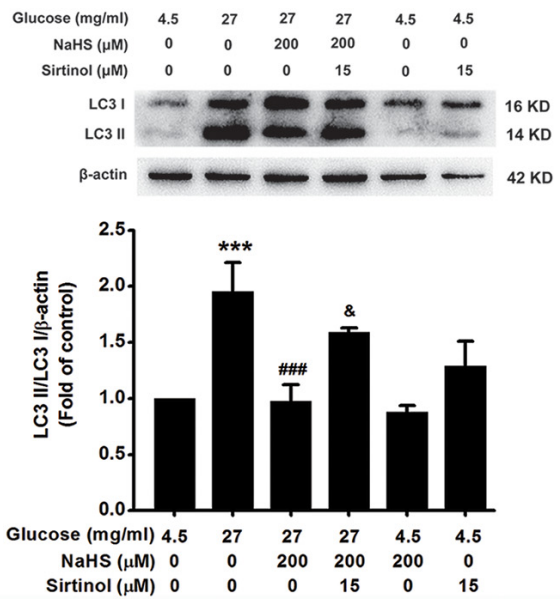

HG

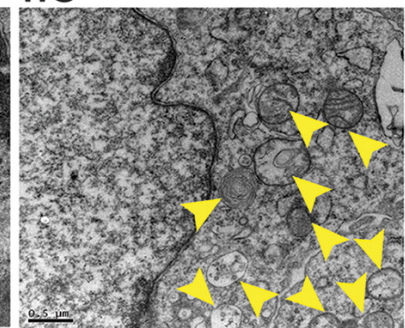

NaHS

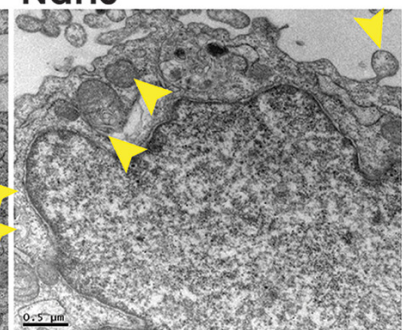

HG+NaHS $(200 \mu M)$

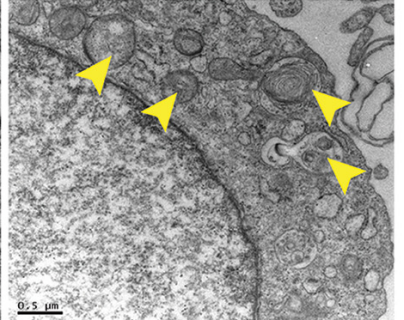

Sirtinol

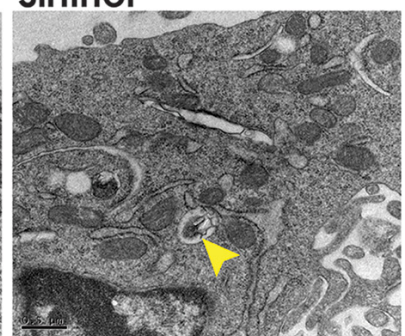

C
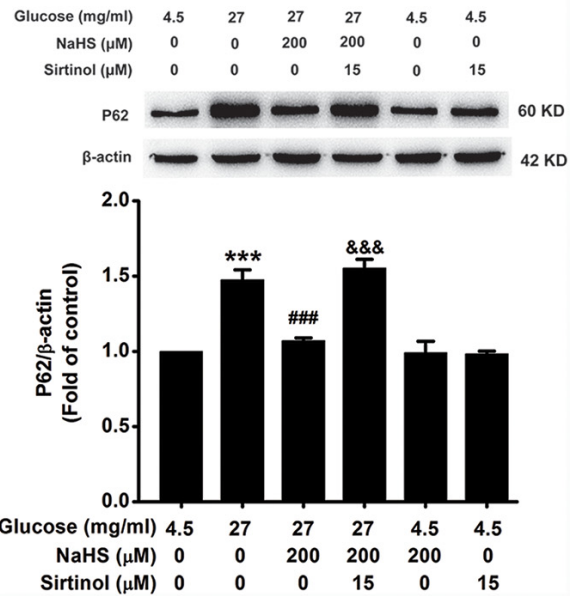

FIGURE 6 | Effect of Sirtinol on the improving effect of $\mathrm{H}_{2} \mathrm{~S}$ on autophagic flux in HG-exposed HT22 cells. (A) Representative transmission electron microscope images of HT22 cells showing the change in the number of autophagosome. The yellow arrows indicate autophagosome. (B,C) The expressions of LC3II/LC3I and P62 in HT22 cells were detected by Western blotting. Values were expressed as the mean $\pm \mathrm{SEM}, n=3$. ${ }^{* * *} P<0.001$, vs. control group; $\# \# \#+0.001$, vs. HG-treated alone group. \& $P<0.05$, \&\&\& $P<0.001$, vs. co-treated with NaHS and HG group.

senescence, we explored whether the inhibition of autophagic flux abolishes the protection of $\mathrm{H}_{2} \mathrm{~S}$. Thus, two autophagy inhibitors, CQ and 3-MA, were used in our research. We found that blockage of autophagic flux by CQ reverses the protection of $\mathrm{H}_{2} \mathrm{~S}$ against $\mathrm{HG}$-induced cellular senescence in HT22 cells. However, 3-MA could not reverse the above effects. Consistent with this notion, prolonged treatment with 3-MA promotes autophagic flux under nutrient-rich conditions ( $\mathrm{Wu}$ et al., 2010). CQ impairs lysosome function that restrains fusion of autophagosome and lysosome, while 3-MA is a type III phosphatidylinositol 3-kinase (PI3KCIII) inhibitor that inhibits autophagy from the initiation step (Pliyev and Menshikov, 2012). These results thus indicated that $\mathrm{H}_{2} \mathrm{~S}$ may block lysosome to rescue HG-impaired autophagic flux in HT22 cells. Taken together, our outcomes indicated that improving autophagic flux mediates the antagonistic action of $\mathrm{H}_{2} \mathrm{~S}$ in HG-induced cellular senescence in HT22 cells. It has been demonstrated that blocking autophagic flux reverses the protective effect of $\mathrm{H}_{2} \mathrm{~S}$ against acrylonitrile-induced neurotoxicity (Yang et al., 2018). Therefore, we suggest that improving autophagic flux contributes to the protective effect of $\mathrm{H}_{2} \mathrm{~S}$ against HG-induced neuronal senescence.

SIRT1 is a NAD ${ }^{+}$-dependent deacetylase. Increasing evidence confirms the anti-senescence effect of SIRT1 (Hwang et al., 2013; Herskovits and Guarente, 2014). While, SIRT1 deficiency induces cellular senescence (Furukawa et al., 2007). Furthermore, it has been reported that SIRT1 prevents oxidative stress-induced cellular senescence via restoration of autophagic flux (Han 


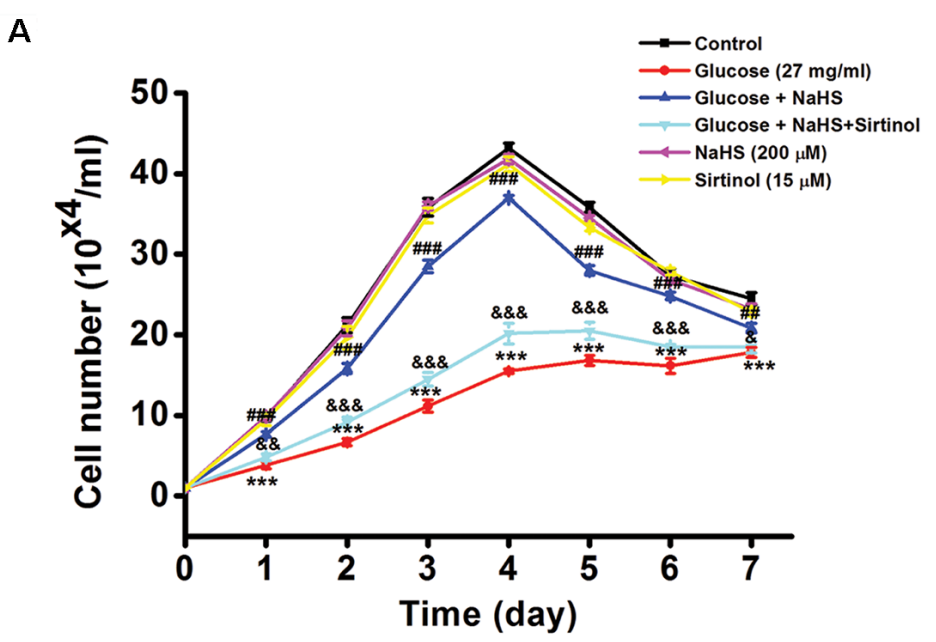

B



C

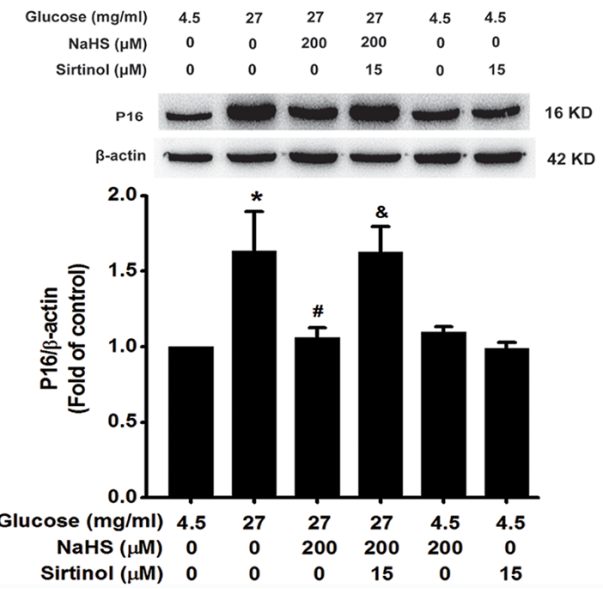

D

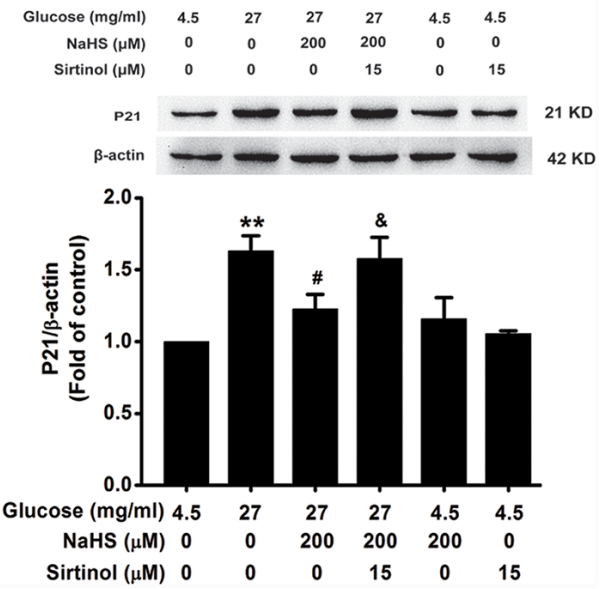

FIGURE 7 | Sirtinol reversed $\mathrm{H}_{2}$ S-inhibited cellular senescence in HG-exposed HT22 cells. (A) Cell growth curves were generated by using Trypan blue stain assays. (B) Representative images of senescent cells that were stained for SA- $\beta$-gal (Left, Magnification $\times 10$ ) and quantitative analysis of the SA- $\beta$-gal positive cell (Right). The black arrows indicate the senescent cells. (C,D) The expressions of LC3II/LC3I and P62 in HT22 cells were detected by Western blotting. Values were expressed as the mean \pm SEM, $n=3$. ${ }^{*} P<0.05$, ${ }^{* *} P<0.01$, ${ }^{* * *} P<0.001$, vs. control group; ${ }^{\#} P<0.05$, ${ }^{\# \#} P<0.01$, \#\#\# $P<0.001$, vs. HG-treated alone group. \& $P<0.05$, \&\& $P<0.001$, \&\&\& $P<0.001$, vs. co-treated with NaHS and HG group.

et al., 2016) and that up-regulation of SIRT1 by resveratrol enhances autophagic flux in human umbilical vein endothelial cell (Zhang et al., 2016). It is reasonable to believe that SIRT1 suppresses cellular senescence via improving autophagic flux. Does SIRT1 mediate the protection of $\mathrm{H}_{2} \mathrm{~S}$ against
HG-induced neuronal senescence in HT22 cells? It has been documented that SIRT1 mediates the roles of $\mathrm{H}_{2} \mathrm{~S}$ in attenuating chronic restraint stress-induced cognitive impairment (Li X. N. et al., 2017) and inhibiting homocysteine-induced endoplasmic reticulum stress in PC12 cells (Wang et al., 2017). Therefore, it 
seems advisable to conjecture that SIRT1 mediates the protection of $\mathrm{H}_{2} \mathrm{~S}$ against $\mathrm{HG}$-triggered neuronal senescence. In the present work, we found that $\mathrm{H}_{2} \mathrm{~S}$ up-regulated the expression of SIRT1 in HG-exposed HT22 cells and that Sirtinol, an inhibitor of SIRT1 abolished the protective effect of $\mathrm{H}_{2} \mathrm{~S}$ on $\mathrm{HG}$-induced cellular senescence in HT22 cells. These results indicated that SIRT1 mediates the protection of $\mathrm{H}_{2} \mathrm{~S}$ against HG-triggered neuronal senescence in HT22 cell. This finding is consistent with the previous report that stimulating of SIRT1 by $\mathrm{H}_{2} \mathrm{~S}$ antagonizes senescence in human fibroblasts (Sanokawa-Akakura et al., 2016) and $\mathrm{H}_{2} \mathrm{O}_{2}$-induced senescence in human umbilical vein endothelial cells (Suo et al., 2013). Furthermore, we found that inhibition of SIRT1 by sirtinol reversed the improving role of $\mathrm{H}_{2} \mathrm{~S}$ in the autophagic flux of HG-exposed HT22 cells. Taken together, we suggested that SIRT1 mediates the protective effect of $\mathrm{H}_{2} \mathrm{~S}$ against HG-induced senescence in HT22 cells via improving autophagic flux.

In summary, our research indicated that $\mathrm{H}_{2} \mathrm{~S}$ increases autophagic flux by up-regulation of SIRT1 expression and thereby antagonizes HG-induced cellular senescence in HT22 cells. These findings provide a deeper mechanism explanation for the protection of $\mathrm{H}_{2} \mathrm{~S}$ against hyperglycemiainduced neuronal senescence and suggest that $\mathrm{H}_{2} \mathrm{~S}$ may

\section{REFERENCES}

Allen, D. A., Yaqoob, M. M., and Harwood, S. M. (2005). Mechanisms of high glucose-induced apoptosis and its relationship to diabetic complications. J. Nutr. Biochem. 16, 705-713. doi: 10.1016/j.jnutbio.2005.06.007

Bahniwal, M., Little, J. P., and Klegeris, A. (2017). High glucose enhances neurotoxicity and inflammatory cytokine secretion by stimulated human astrocytes. Curr. Alzheimer Res. 14, 731-741. doi: 10.2174/15672050146661 70117104053

Baker, D. J., Wijshake, T., Tchkonia, T., LeBrasseur, N. K., Childs, B. G., van de Sluis, B., et al. (2011). Clearance of p16Ink4a-positive senescent cells delays ageing-associated disorders. Nature 479, 232-236. doi: 10.1038/nature10600

Bjørkøy, G., Lamark, T., Brech, A., Outzen, H., Perander, M., Overvatn, A., et al. (2005). p62/SQSTM1 forms protein aggregates degraded by autophagy and has a protective effect on huntingtin-induced cell death. J. Cell Biol. 171, 603-614. doi: $10.1083 /$ jcb.200507002

Bordone, L., and Guarente, L. (2005). Calorie restriction, SIRT1 and metabolism: understanding longevity. Nat. Rev. Mol. Cell Biol. 6, 298-305. doi: $10.1038 / \mathrm{nrm} 1616$

Caro, L. H., Plomp, P. J., Wolvetang, E. J., Kerkhof, C., and Meijer, A. J. (1988). 3Methyladenine, an inhibitor of autophagy, has multiple effects on metabolism. Eur. J. Biochem. 175, 325-329. doi: 10.1111/j.1432-1033.1988.tb14200.x

Carreira, S., Goodall, J., Aksan, I., La Rocca, S. A., Galibert, M. D., Denat, L., et al. (2005). Mitf cooperates with Rb1 and activates p21Cip1 expression to regulate cell cycle progression. Nature 433, 764-769. doi: 10.1038/nature03269

Cohen, H. Y., Miller, C., Bitterman, K. J., Wall, N. R., Hekking, B., Kessler, B., et al. (2004). Calorie restriction promotes mammalian cell survival by inducing the SIRT1 deacetylase. Science 305, 390-392. doi: 10.1126/science. 1099196

Debacq-Chainiaux, F., Erusalimsky, J. D., Campisi, J., and Toussaint, O. (2009). Protocols to detect senescence-associated $\beta$-galactosidase (SA-betagal) activity, a biomarker of senescent cells in culture and in vivo. Nat. Protoc. 4, 1798-1806. doi: 10.1038/nprot.2009.191

Dimri, G. P., Lee, X., Basile, G., Acosta, M., Scott, G., Roskelley, C., et al. (1995). A biomarker that identifies senescent human cells in culture and in aging skin in vivo. Proc. Natl. Acad. Sci. U S A 92, 9363-9367. doi: 10.1073/pnas.92.20. 9363 be a prospective strategy for prevention of hyperglycemiainduced neurotoxicity.

\section{DATA AVAILABILITY}

The raw data supporting the conclusions of this manuscript will be made available by the authors, without undue reservation, to any qualified researcher.

\section{AUTHOR CONTRIBUTIONS}

$\mathrm{X}-\mathrm{QT}$ and H-LH conceived and designed the experiments. YC, LW, C-YW, Y-YT, XL, XK, and Y-RX performed the experiments. X-QT, YC, and LW analyzed the data. C-YW, $\mathrm{Y}-\mathrm{YT}, \mathrm{XL}, \mathrm{XK}$, and Y-RX contributed reagents, materials and analysis tools. X-QT and LW wrote and revised the manuscript.

\section{FUNDING}

This study was supported by Natural Science Foundation of China (81671057) and Natural Science Foundation of Hunan province (2019JJ50546, 2019JJ80101).

Fan, F., Liu, T., Wang, X., Ren, D., Liu, H., Zhang, P., et al. (2016). ClC-3 expression and its association with hyperglycemia induced HT22 hippocampal neuronal cell apoptosis. J. Diabetes Res. 2016:2984380. doi: 10.1155/2016/29 84380

Furukawa, A., Tada-Oikawa, S., Kawanishi, S., and Oikawa, S. (2007). $\mathrm{H}_{2} \mathrm{O}_{2}$ accelerates cellular senescence by accumulation of acetylated p53 via decrease in the function of SIRT1 by NAD ${ }^{+}$depletion. Cell. Physiol. Biochem. 20, 45-54. doi: $10.1159 / 000104152$

Han, X., Tai, H., Wang, X., Wang, Z., Zhou, J., Wei, X., et al. (2016). AMPK activation protects cells from oxidative stress-induced senescence via autophagic flux restoration and intracellular $\mathrm{NAD}^{+}$elevation. Aging Cell 15, 416-427. doi: 10.1111/acel.12446

Herskovits, A. Z., and Guarente, L. (2014). SIRT1 in neurodevelopment and brain senescence. Neuron 81, 471-483. doi: 10.1016/j.neuron.2014.01.028

Hou, J., Zheng, D., Xiao, W., Li, D., Ma, J., and Hu, Y. (2018). Mangiferin enhanced autophagy via inhibiting mTORC1 pathway to prevent high glucose-induced cardiomyocyte injury. Front. Pharmacol. 9:383. doi: 10.3389/fphar.2018. 00383

Hu, L. F., Lu, M., Wu, Z. Y., Wong, P. T., and Bian, J. S. (2009). Hydrogen sulfide inhibits rotenone-induced apoptosis via preservation of mitochondrial function. Mol. Pharmacol. 75, 27-34. doi: 10.1124/mol.108.047985

Hwang, J. W., Yao, H., Caito, S., Sundar, I. K., and Rahman, I. (2013). Redox regulation of SIRT1 in inflammation and cellular senescence. Free Radic. Biol. Med. 61, 95-110. doi: 10.1016/j.freeradbiomed.2013.03.015

Kaur, N., Kishore, L., and Singh, R. (2017). Chromane isolated from leaves of Dillenia indica improves the neuronal dysfunction in STZ-induced diabetic neuropathy. J. Ethnopharmacol. 206, 19-30. doi: 10.1016/j.jep.2017.05.018

Komatsu, M., and Ichimura, Y. (2010). Physiological significance of selective degradation of p62 by autophagy. FEBS Lett. 584, 1374-1378. doi: 10.1016/j. febslet.2010.02.017

Kumar, P., Raman, T., Swain, M. M., Mishra, R., and Pal, A. (2017). Hyperglycemia-induced oxidative-nitrosative stress induces inflammation and neurodegeneration via augmented tuberous sclerosis complex-2 (TSC-2) activation in neuronal cells. Mol. Neurobiol. 54, 238-254. doi: 10.1007/s12035015-9667-3

Li, X. N., Chen, L., Luo, B., Li, X., Wang, C. Y., Zou, W., et al. (2017). Hydrogen sulfide attenuates chronic restrain stress-induced cognitive impairment 
by upreglulation of Sirt1 in hippocampus. Oncotarget 8, 100396-100410. doi: 10.18632 /oncotarget.22237

Li, Y., Zhang, Y., Wang, L., Wang, P., Xue, Y., Li, X., et al. (2017). Autophagy impairment mediated by S-nitrosation of ATG4B leads to neurotoxicity in response to hyperglycemia. Autophagy 13, 1145-1160. doi: 10.1080/15548627. 2017.1320467

Li, X., Zhang, K. Y., Zhang, P., Chen, L. X., Wang, L., Xie, M., et al. (2014). Hydrogen sulfide inhibits formaldehyde-induced endoplasmic reticulum stress in PC12 cells by upregulation of SIRT-1. PLoS One 9:e89856. doi: 10.1371/journal.pone.0089856

Lim, J., Lee, Y., Jung, S., Youdim, M. B., and Oh, Y. J. (2014). Impaired autophagic flux is critically involved in drug-induced dopaminergic neuronal death. Parkinsonism Relat. Disord. 20, S162-S166. doi: 10.1016/s1353-8020(13) 70039-7

Lin, J. R., Shen, W. L., Yan, C., and Gao, P. J. (2015). Downregulation of dynaminrelated protein 1 contributes to impaired autophagic flux and angiogenic function in senescent endothelial cells. Arterioscler. Thromb. Vasc. Biol. 35, 1413-1422. doi: 10.1161/atvbaha.115.305706

Liu, J., Li, L., and Suo, W. Z. (2009). HT22 hippocampal neuronal cell line possesses functional cholinergic properties. Life Sci. 84, 267-271. doi: 10.1016/j. lfs.2008.12.008

Liu, Y. Y., Nagpure, B. V., Wong, P. T., and Bian, J. S. (2013). Hydrogen sulfide protects SH-SY5Y neuronal cells against d-galactose induced cell injury by suppression of advanced glycation end products formation and oxidative stress. Neurochem. Int. 62, 603-609. doi: 10.1016/j.neuint.2012. 12.010

Liu, C., Song, Z., Wang, L., Yu, H., Liu, W., Shang, Y., et al. (2017). Sirtl regulates acrosome biogenesis by modulating autophagic flux during spermiogenesis in mice. Development 144, 441-451. doi: 10.1242/dev.147074

Liu, R. Y., Wang, J. J., Qiu, X., and Wu, J. M. (2014). Acute hyperglycemia together with hematoma of high-glucose blood exacerbates neurological injury in a rat model of intracerebral hemorrhage. Neurosci. Bull. 30, 90-98. doi: 10.1007/s12264-013-1371-6

Lumkwana, D., du Toit, A., Kinnear, C., and Loos, B. (2017). Autophagic flux control in neurodegeneration: progress and precision targeting-Where do we stand? Prog. Neurobiol. 153, 64-85. doi: 10.1016/j.pneurobio.2017.03.006

Menzies, F. M., Fleming, A., and Rubinsztein, D. C. (2015). Compromised autophagy and neurodegenerative diseases. Nat. Rev. Neurosci. 16, 345-357. doi: $10.1038 / \mathrm{nrn} 3961$

Mizushima, N., Levine, B., Cuervo, A. M., and Klionsky, D. J. (2008). Autophagy fights disease through cellular self-digestion. Nature 451, 1069-1075. doi: 10.1038/nature06639

Nixon, R. A. (2013). The role of autophagy in neurodegenerative disease. Nat. Med. 19, 983-997. doi: $10.1038 / \mathrm{nm} .3232$

Panthi, S., Chung, H. J., Jung, J., and Jeong, N. Y. (2016). Physiological importance of hydrogen sulfide: emerging potent neuroprotector and neuromodulator. Oxid. Med. Cell. Longev. 2016:9049782. doi: 10.1155/2016/9049782

Pliyev, B. K., and Menshikov, M. (2012). Differential effects of the autophagy inhibitors 3-methyladenine and chloroquine on spontaneous and TNF- $\alpha$ induced neutrophil apoptosis. Apoptosis 17, 1050-1065. doi: 10.1007/s10495012-0738-x

Qadir, M. I., and Anwar, S. (2017). Sirtuins in brain aging and neurological disorders. Crit. Rev. Eukaryot. Gene Expr. 27, 321-329. doi: 10.1615/critreveukaryotgeneexpr.2017019532

Qi, H. N., Cui, J., Liu, L., Lu, F. F., Song, C. J., Shi, Y., et al. (2012). Exogenous hydrogen sulfide delays the senescence of human umbilical vein endothelial cells by lessening oxidative stress. Sheng Li Xue Bao 64, 425-432, doi: 10.1016/j. jacc.2014.06.211

Renaud, J., Bassareo, V., Beaulieu, J., Pinna, A., Schlich, M., Lavoie, C., et al. (2018). Dopaminergic neurodegeneration in a rat model of long-term hyperglycemia: preferential degeneration of the nigrostriatal motor pathway. Neurobiol. Aging 69, 117-128. doi: 10.1016/j.neurobiolaging.2018.05.010

Reno, C. M., Tanoli, T., Bree, A., Daphna-Iken, D., Cui, C., Maloney, S. E., et al. (2013). Antecedent glycemic control reduces severe hypoglycemia-induced neuronal damage in diabetic rats. Am. J. Physiol. Endocrinol. Metab. 304, E1331-E1337. doi: 10.1152/ajpendo.00084.2013

Sanokawa-Akakura, R., Akakura, S., and Tabibzadeh, S. (2016). Replicative senescence in human fibroblasts is delayed by hydrogen sulfide in a NAMPT/SIRT1 dependent manner. PLoS One. 11:e0164710. doi: 10.1371/journal.pone.0164710

Shen, D. N., Zhang, L. H., Wei, E. Q., and Yang, Y. (2015). Autophagy in synaptic development, function, and pathology. Neurosci. Bull. 31, 416-426. doi: 10.1007/s12264-015-1536-6

Si, Y. F., Wang, J., Guan, J., Zhou, L., Sheng, Y., and Zhao, J. (2013). Treatment with hydrogen sulfide alleviates streptozotocin-induced diabetic retinopathy in rats. Br. J. Pharmacol. 169, 619-631. doi: 10.1111/bph.12163

Sima, A. A., Kamiya, H., and Li, Z. G. (2004). Insulin, C-peptide, hyperglycemia, and central nervous system complications in diabetes. Eur. J. Pharmacol. 490, 187-197. doi: 10.1016/j.ejphar.2004.02.056

Sinadinos, C., Valles-Ortega, J., Boulan, L., Solsona, E., Tevy, M. F., Marquez, M., et al. (2014). Neuronal glycogen synthesis contributes to physiological aging. Aging Cell 13, 935-945. doi: 10.1111/acel.12254

Song, J., Lee, B., Kang, S., Oh, Y., Kim, E., Kim, C. H., et al. (2016). Agmatine ameliorates high glucose-induced neuronal cell senescence by regulating the p21 and p53 signaling. Exp. Neurobiol. 25, 24-32. doi: 10.5607/en.2016.25.1.24

Sun, L., Zhang, S., Yu, C., Pan, Z., Liu, Y., Zhao, J., et al. (2015). Hydrogen sulfide reduces serum triglyceride by activating liver autophagy via the AMPK-mTOR pathway. Am. J. Physiol. Endocrinol. Metab. 309, E925-E935. doi: 10.1152/ajpendo.00294.2015

Suo, R., Zhao, Z. Z., Tang, Z. H., Ren, Z., Liu, X., Liu, L. S., et al. (2013). Hydrogen sulfide prevents $\mathrm{H}_{2} \mathrm{O}_{2}$-induced senescence in human umbilical vein endothelial cells through SIRT1 activation. Mol. Med. Rep. 7, 1865-1870. doi: $10.3892 / \mathrm{mmr} .2013 .1417$

Suzuki, K., Olah, G., Modis, K., Coletta, C., Kulp, G., Gerö, D., et al. (2011). Hydrogen sulfide replacement therapy protects the vascular endothelium in hyperglycemia by preserving mitochondrial function. Proc. Natl. Acad. Sci. US A 108, 13829-13834. doi: 10.1073/pnas.1105121108

Tennant, J. R. (1964). Evaluation of the trypan blue technique for determination of cell viabilty. Transplantation 2, 685-694. doi: 10.1097/00007890-19641100000001

Tomlinson, D. R., and Gardiner, N. J. (2008). Glucose neurotoxicity. Nat. Rev. Neurosci. 9, 36-45. doi: 10.1038/nrn2294

Wang, R. (2010). Hydrogen sulfide: the third gasotransmitter in biology and medicine. Antioxid. Redox Signal. 12, 1061-1064. doi: 10.1089/ars.2009.2938

Wang, C. Y., Zou, W., Liang, X. Y., Jiang, Z. S., Li, X., Wei, H. J., et al. (2017). Hydrogen sulfide prevents homocysteineinduced endoplasmic reticulum stress in PC12 cells by upregulating SIRT1. Mol. Med. Rep. 16, 3587-3593. doi: 10.3892/mmr.2017.7004

Ward, R., and Ergul, A. (2016). Relationship of endothelin-1 and NLRP3 inflammasome activation in HT22 hippocampal cells in diabetes. Life Sci. 159, 97-103. doi: 10.1016/j.lfs.2016.02.043

Wei, H. J., Xu, J. H., Li, M. H., Tang, J. P., Zou, W., Zhang, P., et al. (2014). Hydrogen sulfide inhibits homocysteine-induced endoplasmic reticulum stress and neuronal apoptosis in rat hippocampus via upregulation of the BDNF-TrkB pathway. Acta Pharmacol. Sin. 35, 707-715. doi: 10.1038/aps. 2013.197

Wu, Y. T., Tan, H. L., Shui, G., Bauvy, C., Huang, Q., Wenk, M. R., et al. (2010). Dual role of 3-methyladenine in modulation of autophagy via different temporal patterns of inhibition on class I and III phosphoinositide 3-kinase. J. Biol. Chem. 285, 10850-10861. doi: 10.1074/jbc.M109.080796

Xie, J., Cui, K., Hao, H., Zhang, Y., Lin, H., Chen, Z., et al. (2016). Acute hyperglycemia suppresses left ventricular diastolic function and inhibits autophagic flux in mice under prohypertrophic stimulation. Cardiovasc. Diabetol. 15:136. doi: 10.1186/s12933-016-0452-Z

Xie, Z. Z., Shi, M. M., Xie, L., Wu, Z. Y., Li, G., Hua, F., et al. (2014). Sulfhydration of p66Shc at cysteine59 mediates the antioxidant effect of hydrogen sulfide. Antioxid. Redox Signal. 21, 2531-2542. doi: 10.1089/ars.2013. 5604

Xie, H., Xu, Q., Jia, J., Ao, G., Sun, Y., Hu, L., et al. (2015). Hydrogen sulfide protects against myocardial ischemia and reperfusion injury by activating AMP-activated protein kinase to restore autophagic flux. Biochem. Biophys. Res. Commun. 458, 632-638. doi: 10.1016/j.bbrc.2015.02.017

Yang, B., Bai, Y., Yin, C., Qian, H., Xing, G., Wang, S., et al. (2018). Activation of autophagic flux and the Nrf2/ARE signaling pathway by hydrogen sulfide protects against acrylonitrile-induced neurotoxicity in primary rat astrocytes. Arch. Toxicol. 92, 2093-2108. doi: 10.1007/s00204-018-2208-x 
Yang, F., Zhang, L., Gao, Z., Sun, X., Yu, M., Dong, S., et al. (2017). Exogenous $\mathrm{H} 2 \mathrm{~S}$ protects against diabetic cardiomyopathy by activating autophagy via the AMPK/mTOR pathway. Cell. Physiol. Biochem. 43, 1168-1187. doi: $10.1159 / 000481758$

Yang, G., Zhao, K., Ju, Y., Mani, S., Cao, Q., Puukila, S., et al. (2013). Hydrogen sulfide protects against cellular senescence via S-sulfhydration of Keap1 and activation of Nrf2. Antioxid. Redox Signal. 18, 1906-1919. doi: 10.1089/ars. 2012.4645

Ye, H., Chen, M., Cao, F., Huang, H., Zhan, R., and Zheng, X. (2016). Chloroquine, an autophagy inhibitor, potentiates the radiosensitivity of glioma initiating cells by inhibiting autophagy and activating apoptosis. BMC Neurol. 16:178. doi: 10.1186/s12883-016-0700-6

Yerra, V. G., Areti, A., and Kumar, A. (2017). Erratum to: adenosine monophosphate-activated protein kinase abates hyperglycaemia-induced neuronal injury in experimental models of diabetic neuropathy: effects on mitochondrial biogenesis, autophagy and neuroinflammation. Mol. Neurobiol. 54, 2313-2314. doi: 10.1007/s12035-016-0183-x

Yin, Y., Sun, G., Li, E., Kiselyov, K., and Sun, D. (2017). ER stress and impaired autophagy flux in neuronal degeneration and brain injury. Ageing Res. Rev. 34, 3-14. doi: 10.1016/j.arr.2016.08.008

Zhang, Y., Cao, X., Zhu, W., Liu, Z., Liu, H., Zhou, Y., et al. (2016). Resveratrol enhances autophagic flux and promotes Ox-LDL degradation in HUVECs via upregulation of SIRT1. Oxid. Med. Cell. Longev. 2016:7589813. doi: 10.1155/2016/7589813

Zhang, L., Chen, Z. W., Yang, S. F., Shaer, M., Wang, Y., Dong, J. J., et al. (2019). MicroRNA-219 decreases hippocampal long-term potentiation inhibition and hippocampal neuronal cell apoptosis in type 2 diabetes mellitus mice by suppressing the NMDAR signaling pathway. CNS Neurosci. Ther. 25, 69-77. doi: $10.1111 / \mathrm{cns} .12981$
Zhang, Q., Deng, Q., Zhang, J., Ke, J., Zhu, Y., Wen, R. W., et al. (2018). Activation of the Nrf2-ARE pathway ameliorates hyperglycemia-mediated mitochondrial dysfunction in podocytes partly through Sirt1. Cell. Physiol. Biochem. 48, 1-15. doi: 10.1159/000491658

Zhang, Y., Tang, Z. H., Ren, Z., Qu, S. L., Liu, M. H., Liu, L. S., et al. (2013). Hydrogen sulfide, the next potent preventive and therapeutic agent in aging and age-associated diseases. Mol. Cell. Biol. 33, 1104-1113. doi: 10.1128/mcb. 01215-12

Zhang, Y., Thai, K., Jin, T., Woo, M., and Gilbert, R. E. (2018). SIRT1 activation attenuates $\alpha$ cell hyperplasia, hyperglucagonaemia and hyperglycaemia in STZ-diabetic mice. Sci. Rep. 8:13972. doi: 10.1038/s41598-01832351-Z

Zhu, W. W., Xiao, F., Tang, Y. Y., Zou, W., Li, X., Zhang, P., et al. (2018). Spermidine prevents high glucose-induced senescence in HT-22 cells by upregulation of CB1 receptor. Clin. Exp. Pharmacol. Physiol. 45, 832-840. doi: $10.1111 / 1440-1681.12955$

Conflict of Interest Statement: The authors declare that the research was conducted in the absence of any commercial or financial relationships that could be construed as a potential conflict of interest.

Copyright (c) 2019 Wu, Chen, Wang, Tang, Huang, Kang, Li, Xie and Tang. This is an open-access article distributed under the terms of the Creative Commons Attribution License (CC BY). The use, distribution or reproduction in other forums is permitted, provided the original author(s) and the copyright owner(s) are credited and that the original publication in this journal is cited, in accordance with accepted academic practice. No use, distribution or reproduction is permitted which does not comply with these terms. 